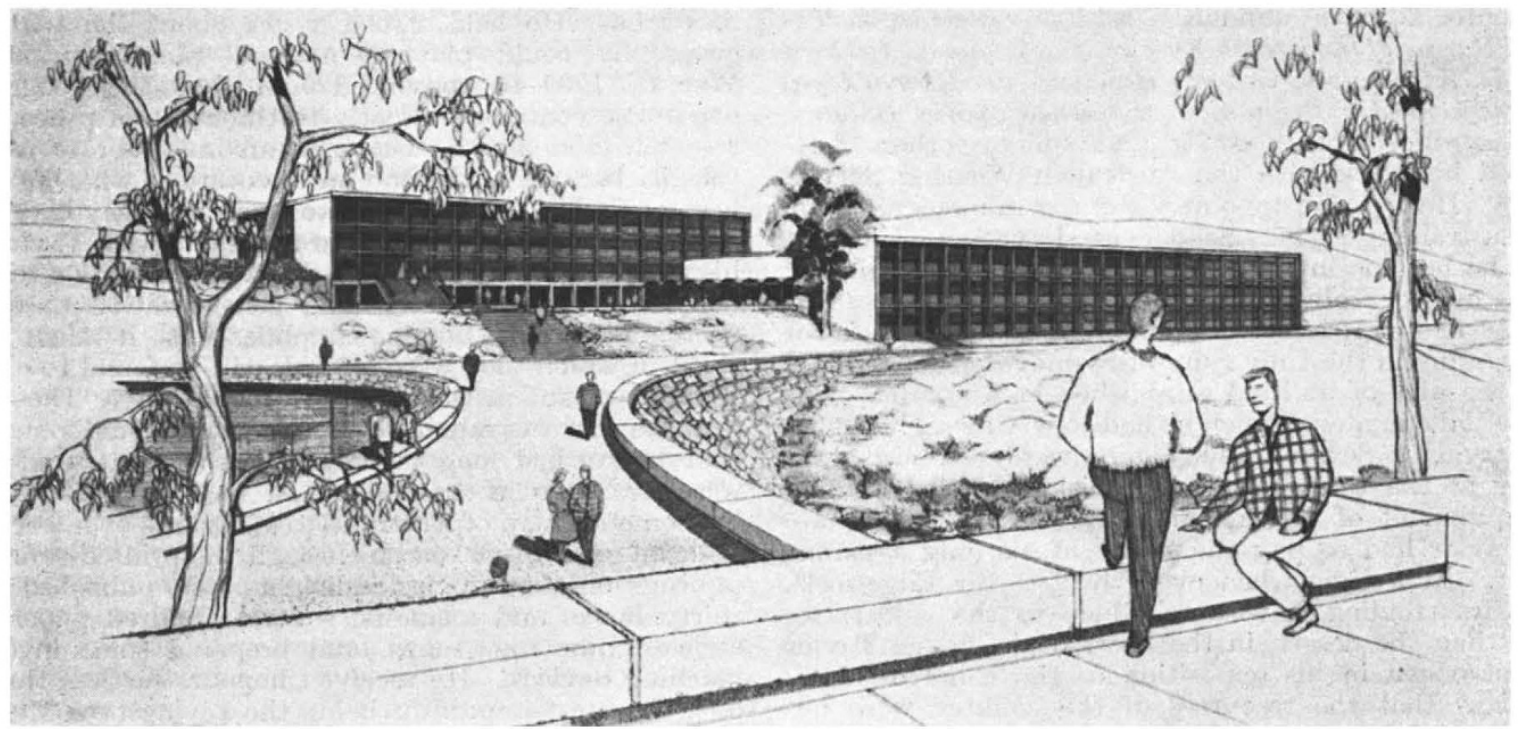

Fig. 3. The science buildings looking south across the causeway. The building on the left, which encloses a courtyard, will house the School of Physical Sciences. It is linked by a pair of lecture theatres to the School of Biological Sciences on the right

disciplines is planned as well as flexibility to allow for changes in emphasis. Groups of cognate courses will be developed in association with several professors and corresponding groups of sub-professorial staff.

As the unity rather than the diversity of living organisms will be stressed, considerable emphasis will be placed. on cellular biology, molecular biology and morphogenesis. The study of experimental morphogenesis is not well developed in Australia and it is hoped that Bedford Park will be able to make a valuable contribution towards strengthening this field. The detailed organization of the undergraduate courses will be undertaken when further members of academic staff have been appointed, but the present intention is that emphasis will be placed on the molecular, cellular and population levels of organization. It is anticipated that relatively advanced equipment will be available for undergraduate teaching as well as for research.

Two additional chairs of biology will be filled during 1964 and the University hopes to appoint biologists whose interests fall broadly within the fields of cell biochemistry, cell physiology or experimental morphogenesis.

The Bedford Park site comprises 370 acres in the foothills of the Mount Lofty Range and about three miles from the sea. It is deeply dissected by a number of valleys and there is a difference in height of more than $300 \mathrm{ft}$. between the highest and lowest points. Stimulated by the difficulties of the terrain, the site planners have evolved an imaginative development scheme which takes full account of the natural advantages which the site has to offer.

The first stage of the site works and building programme, which has already begun, involves an expenditure of £A3 million, and includes the erection of buildings for the four academic Schools, the library, the union and the administration, and a hall of residence to accommodate 200 students. The buildings will be completed, furnished and equipped and ready for occupation by the end of 1965 ,

Initially, the academic buildings will form two major groups each located on the erest of a ridge and separated. by a small but steep gully. A dam is to be constructed in the gully and the two building groups will be linked by a broad pedestrian causeway across the top of the dam. The gully itsolf will be developed and beautified as a park surrounding the water stored in the dam. The buildings have been sited and planned in such a way that once they have been completed and their environs landscaped it will not be necessary to disrupt the completed areas when the time comes to undortake further building construction or site works. Figs. 2 and $\mathbf{3}$ are the architects' impressions of how each group of buildings will appear when viewed from the other.

Enrolments in the four Schools in 1966 are expected to be about 500 . Work in fields outside those covered by the first four Sohools will be added as the need arises. It is envisaged that student numbers will rise to 2,000 by the early 1970's and to 5,000 by the 1980's.

\title{
OBITUARY
}

\section{Prof. Griffith Taylor, F.A.A.}

Griffith TAylor, who died at Sydney, New South Wales, on November 5, was born at Walthamstow, Essex, on December 1, 1880, but spent his earliest years in Serbia. His father, James Taylor, a mining engineer, was appointed Government metallurgist to the State of New South Wales in 1893. Griffith Taylor graduated in science in the University of Sydney in 1904 and took his B.E. there in 1905 . In 1907 he went to Cambridge to complete the exhaustive work he had been doing on the Archaeocyathinae. On his return to Australia in 1910 he was appointed physiographer to the Australian Weather Service, and at once began the long series of studies in Australian goomorphology and climatology, which became the foundation of all his later work. Towards the end of 1910 he was appointed senior geologist to the British Antarctic Expedition. His two years with Scott undoubtedly developed a capacity for leadership and an ability to stand alone against adversity, which sustained him during his long life as a professor of geography and an opponent of ill-founded optimism. The experience also brought forth one of the more important of his many books, With Scott-The Silver Lining (London, 1915), and established him as an authority on the geology and geography of Antarctica. Herbertson and Howarth sought his collaboration for their Australasia (Oxford, 1912), and, from that time on, Taylor was an important 
contributor to such standard works of reference as The Oxford Survey of the British Empire, Die Regionale Geologie der Erde, Köppen and Geiger's Handbuch der Klimatologie, the Encyclopcedia Britannica, the Enciclopedia Italiana, the Australian Encyclopcedia and sundry othors. $\mathrm{He}$ resumed his work with the Australian Woather Service in 1914. He was also appointed lecturer in meteorology in the Australian Flying School at Laverton, Victoria, where he became interested in the political and military aspects of geography.

At the end of 1920 he was appointed associate professor of geography in the University of Sydney, his department being the first of its kind established in Australia. The intelloctual climate in which ho had to work was, however, most trying. Several new chairs were established at Sydney at the time, but the provision for the staffing and equipment of new departments was so inadequate that Taylor had to pay the salary of his only assistant himself. At a time when even the late Sir Edgeworth David was finding it wise to allude to tho wilderness, rather than the desert, in the heart of Australia, Taylor was outspoken in his opposition to the belief of many politicians that the resources of the country were unlimited: and, at a time when the challenge to Nordic supremacy was under discussion in such works as Madison Grant's Passing of the Great Race and Spongler's Der Untergang des Abendlandes, Taylor began to express unwelcome views about race and environment.

He founded the Geographical Society of New South Wales and its journal, The Australian Geographer; but, when Chicago offered him the opportunity of continuing his work under conditions more tolerant than he knew in Sydney, he took it. He was senior professor of geography at the University of Chicago from 1929 until 1935, when he became the first professor of geography to be appointed in Canada. He remained at the University of Toronto until 1951, when he retired to live for the rest of his life in
Australia. He held strong views about the part that geography could play in national planning, and the War of 1939-45 convinced him that the geographer could also contribute greatly to the cause of peace. The research student who began as an invertebrate palæon. tologist becamo in the end an advocate of what he called 'geopacifics'. "Too versatile to be sound", say his critics: and it is, in fact, very easy to find fault with Taylor and his work in matters of detail. He was primarily a teacher. and one who preferred broad generalization to carefiul particularization; but his simplifications, if taken in the spirit in which they were offered, will be found to express what he meant in the clearest possible way. Those who criticize his Australian geomorphology should remembes that he worked long before large-scale contoured maps were available in Australia. In fact, the first reliable hypsometric map of Australia was Taylor's own, compiled after an exhaustive search through the printed sources of information about recorded heights. He published about thirty books and memoirs, several hundred papers and articles, numerous maps, and prepared some ingenious teaching devices. He received honours far less than his due, the most important being the Livingstone Medal of the American Geographical Society of New York (1923). the fellowship of the Australian Academy of Science (1954), and the doctorate of lotters (Sydney, 1959). He presided over the geographical section of the British Association in 1938, over the Association of American Geographers in 1941 and over the Institute of Australian Geographers at its foundation (1959). To the end of his life geography, to him, was essentially a field study, and he set out, at the age of eighty, to walk from Sydney to Melbourne, only to find that the road now has no place for pedestrians.

Taylor married a sister of one of his Antarctic colleagues. Sir Raymond Priestley. Mrs. Taylor and two sons survive him.

\section{NEWS and VIEWS}

The Royal Society: S. G. Brown Medal and Award

THE Council of the Royal Society, having received a bequest under the Will of the late S. G. Brown, has established a fund, the income from which will be used to offer annually an S. G. Brown Medal and Award. The Award will be for an outstanding contribution, based on work carried out during the preceding five years, to the promotion and development of mechanical inventions. The Councils of the Institutions of Civil, Mechanical and Electrical Engineers have agreed to participate by rotation in the selection of a candidate for the Award, who should preferably be under the age of 40 . The first recommendation will be made by the Institution of Civil Engineers to the Council of the Royal Society in March 1964.

Brown, who died in 1948 (Nature, 162,$361 ; 1948$ ), was well known for his numerous inventions. He claimed to have taken out about a thousand patents, commeneing when sixteen with a home-made phonograph. Perhaps his best-known invention was the gyroseopic compass, an instrument which was put to use during the First World War by both the Navy and the Air Force. Although born in Chicago in 1873, Brown was brought to Great Britain at an early age and was educated at Harrowgate College and University College, London. He was elected a Fellow of the Royal Society in 1916.

\section{Pure Mathematics at the University of Manchester:}

Prof. M. G. Barratt

DR. M. G. BARRATT, senior lecturer in mathematics in the University of Manchester, has been appointed to a newly established additional chair of pure mathematies at the University of Manchester from October 1. Dr. Barratt gained his initial education at the Stationers' Company' School, London, from which he proceeded to Brasenose College, Oxford, as a Scholar. After obtaining a first class in mathematics in Moderations in 1946 and in Finals in 1948, he continued as a graduate student and was elected Senior Mathematical Scholar and Johnson University Scholar in 1950 . He was appointed in the same year to a junior lectureship in the University of Oxford and became a Fellow of Magdalen College in 1952. He became Hulme. Lecturer in Brasenose College in 1955 and spent the year 1956-57 in the United States as a visiting assistant professor at Princeton University and as a research associate. at Chicago University. In 1959 he was appointed to his present post as senior lecturer in the Department of Mathematics in the University of Manchester. $\mathrm{He}$ is at present spending a year on leave as visiting professor in Chicago University.

\section{Education in Metallurgy}

IN view of the growth of the many sides of the Institution of Metallurgists' educational work, the Council has appointed Mr. N. P. Atkinson as education officer. Mr. Atkinson was previously education and training officer at Joseph Lucas (Industries), Ltd., and took up his appointment with the Institution on February 1.

The prime objective of the Institution of Metallurgist: "is to promote, encourage, advance and co-ordinate the study and science of metallurgy in all its aspects". Acting in this light, the Institution has, since its foundation in 1945 , directed attention to education in metallurgy as i1 affects students, universities and technical colleges, industry, the Government and nation. The activities of the 